\title{
IMPEACHMENT - CRIME DE RESPONSABILIDADE - EXONERAÇÃO DO CARGO
}

\section{LUÍS ROBERTO BARROSO*}

I. Crimes de responsabilidade e processo de impeachment: análise sumária dos aspectos essenciais - II. Não é possível a instauração de processo por crime de responsabilidade quando o acusado não mais ocupe o cargo do qual era passível de destituição - III. Em face da legislação aplicável, $o$ ato de instauração do processo de impeachment é a aprovação pela Assembléia Legislativa, por quorum constitucional de dois terços dos seus membros, do Projeto de Decreto Legislativo previsto regimentalmente, $e$ não a mera aprovação do parecer da Comissão Parlamentar Especial. - IV. O requisito para instauraçāo do processo por crime de responsabilidade é que o agente político não tenha deixado o cargo. É indiferente para os fins da legislação, se é hipótese foi de renúncia ou de exoneração. $-V$. Os crimes de responsabilidade a serem definidos em lei especial, como prevê o parágrafo único do art. 85 da Constituição Federal, só podem ser os que correspondam às figuras típicas constantes do corpo do dispositivo. Trata-se de matéria de reserva constitucional, insuscetível de extensão discricionária por parte do legislador - VI. Conclusão

Consulta-me o ilustre advogado brasiliense, Dr. Antonio Carlos de Almeida Castro, acerca de aspectos relativos ao processo por crime de responsabilidade instaurado contra cliente seu, ex-Secretário de Estado de Fazenda de Santa Catarina. A hipótese encontra-se narrada a seguir.

O consulente impetrou, em favor de seu cliente, mandado de segurança contra o ato do Presidente da Assembléia Legislativa do Estado de Santa Catarina consistente na submissão, ao Plenário daquela Casa, do projeto de decreto legislativo de instauração de processo por crime de responsabilidade conexo com o imputado ao Governador do Estado. Fundou-se o mandamus em que, quando da prática do ato impugnado, o impetrante não mais ocupava o cargo de Secretário de Estado, por lhe haver sido concedida exoneração a pedido, não estando sujeito, por via de conseqüência, ao processo de impeachment.

* Professor Titular de Direito Constitucional da Universidade do Estado do Rio de Janeiro; Master of Laws pela Yale Law School; Procurador do Estado do Rio de Janeiro.

R. Dir. Adm.,

Rio de Janeiro, 212: 161-174, abr./jun. 1998 
O Excelentíssimo Senhor Desembargador Relator do mandado de segurança, ao apreciar o pedido de liminar, entendeu por bem denegá-lo, por supor ausente o periculum in mora, e fundando-se, ademais, em que:

a) a instauração do processo contra o impetrante dera-se em momento anterior, com o acolhimento, pela Assembléia Legislativa, do parecer da Comissão Especial designada para apreciar a denúncia oferecida;

b) na hipótese de exoneração, diferentemente do que se passa com a renúncia, não se subtrai o servidor às penas da lei, consoante dispõem a Lei do Regime Jurídico Único dos Servidores Públicos da União e o Estatuto dos Funcionários Públicos do Estado.

O presente estudo, após algumas considerações sumárias sobre a natureza, partes, fundamentos e objeto do processo de impeachment, pretende demonstrar que:

I. Não é possível a instauração de processo por crime de responsabilidade contra agente político que já não ocupe mais o cargo que o sujeitava a tal procedimento;

II. Em face da legislação aplicável, o ato de instauração do processo de impeachment é a aprovação pela Assembléia Legislativa, mediante quorum constitucional de dois terços dos seus membros, do projeto de decreto legislativo previsto regimentalmente, e não a mera aprovação do parecer da Comissão Parlamentar Especial;

III. O requisito para instauração do processo por crime de responsabilidade é que o agente político não tenha deixado o cargo. É indiferente, para os fins da legislação, se a hipótese foi de renúncia ou de exoneração;

IV. Os crimes de responsabilidade a serem definidos em lei especial, como prevê o parágrafo único do art. 85 da Constituição Federal, só podem ser os que correspondam às figuras típicas constantes do corpo do dispositivo. Trata-se de reserva constitucional, insuscetível de extensão discricionária por parte do legislador.

A seguir a análise de cada um dos argumentos.

\section{Crimes de responsabilidade e processo de impeachment: análise sumária dos aspectos essenciais ${ }^{t}$}

Crimes de responsabilidade são aqueles suscetíveis de ser praticados por determinados agentes políticos, em razão dos cargos públicos que ocupam. A Constituição da República faz uma capitulação genérica dos delitos dessa natureza nos incisos II

1 Vejam-se, a respeito do tema: Paulo Brossard, $O$ impeachment; Humberto Ribeiro Soares, Impeachment - crimes de responsabilidade do Presidente da República; Denise Freitas Fabiāo Guasque, $O$ "impeachment" do Presidente da República (RT 684/400); Ives Gandra da Silva Martins, Aspectos procedimentais do instituto jurídico do "Impeachment" e conformação da figura da improbidade administrativa (RT 685/286); Antônio Cláudio de Lima Vieira, Sobre o "Impeachment" na Câmara dos Deputados (RT 685/403); Roberto Delmanto e Roberto Delmanto Júnior, A ilegitimidade processual dos autores do pedido de "Impeachment" (RT 690/410); Carlos Eduardo Thompson Flores Lenz, A intervençāo do Judiciário no processo de "Impeachment" (RT 695/262); Paulo Lopo Saraiva, A função judicante do Poder Legislativo no Brasil (RILSF 127/43); Sérgio Sérvulo da Cunha, Responsabilidade política $e$ "Impeachment" (RTDP 5/225): Fernando Whitaker da Cunha, O Poder Legislativo e o "Impeachment" (RILSF 116/31): Barbosa Lima Sobrinho, As sanf̧oes do "Impeachment" (RPGE-RJ 46/1). Veja-se. também. Impeachment, publicação do Supremo Tribunal Federal com as principais decisões sobre crimes de responsabilidade do Presidente da República. 
a VII do art. 85, prevendo, ainda, no parágrafo único do dispositivo: "Esses crimes serão definidos em lei especial, que estabelecerá as normas de processo e julgamento".

Embora não seja empregado no texto constitucional ou na legislação, o termo inglês impeachment é utilizado, de forma ampla, para identificar o processo mediante o qual se promove a apuração e o julgamento dos crimes de responsabilidade. Não obstante remeta a matéria à legislação ordinária, como visto acima, a Constituição Federal institui, ela própria, algumas regras procedimentais a serem seguidas (v. arts. 51, I, 52, I e II, e 86). A Lei 1.079, de 10/04/50, define os crimes de responsabilidade e regula o processo respectivo.

Não é de proveito, nas circunstâncias, qualquer esforço de erudição na busca das raízes históricas do instituto e sua evolução. Basta o registro de que surgiu na Grã-Bretanha, com conteúdo político e penal, sendo abandonado naquele país, ao longo dos anos, substituído por mecanismos próprios do sistema parlamentar. $\mathrm{O}$ constitucionalismo norte-americano o importou, em 1787, como instrumento próprio de responsabilização dos governantes e outros agentes políticos no sistema presidencial, com índole estritamente política.

No Brasil, os mecanismos substantivos e processuais de responsabilização do Presidente da República e outros agentes políticos foram introduzidos com a Constituição de 1891, havendo constado de todas as Cartas subsequientes. Em plano infraconstitucional, três diplomas trataram do tema: a Lei $n^{\mathcal{Q}} 27$, de 7/01/1892; a Lei $\mathrm{n}^{2} 30$, de 8/01/1892; e a Lei $\mathrm{n}^{2} 1.079$, de 10/04/50, ainda em vigor em sua maior parte, consoante reiterado por decisão do Supremo Tribunal Federal. ${ }^{2}$

$O$ processo dos crimes de responsabilidade mereceu tratamento peculiar na Constituição em vigor, sendo que o tema, por força das vicissitudes da história recente do país, foi amplamente debatido na doutrina e na jurisprudência do Supremo Tribunal Federal. Parece bem, assim, em desfecho destas notas conceituais, abordar, sempre com a brevidade conveniente, aspectos referentes à natureza, às partes, aos fundamentos e ao objeto do processo de impeachment. ${ }^{3}$

Influenciada pela sistemática norte-americana, parte da doutrina militou na crença, hoje vencida, de que o processo por crime de responsabilidade teria natureza integralmente política. Como conseqüência de tal ponto de vista, sustentou-se faltar jurisdição ao Poder Judiciário para conhecer de quaisquer questões afetas ao tema. ${ }^{4}$ É inegável que o processo de impeachment tem uma dimensão política, tanto pela natureza dos interesses em jogo e das pessoas envolvidas, como, notadamente, por duas circunstâncias: a) não podem os órgãos do Poder Judiciário rever o mérito da

2 Em seu voto condutor no MS 21.689-DF, consignou o Ministro Carlos Mário Velloso: "A Lei $\mathrm{n}^{\mathrm{g}}$ 1.079 , de 1950 , editada sob o pálio da $\mathrm{CF} / 46$, que foi recepcionada em sua grande parte pela $\mathrm{CF} / 88$, é a lei referida no parágrafo único do art. 85".

3 Não é própria a tradução literal por impeachment, termo que, na verdade, identifica outra situação: a impossibilidade temporária para o exercício do cargo por circunstâncias como viagem ou doença.

4 O principal divulgador deste entendimento foi o ex-Senador e ex-Ministro do STF Paulo Brossard, em sua obra $O$ lmpeachment e em votos sucessivos no STF. No julgamento do MS 20.941-DF, aderiram a tal ponto de vista os Ministros Sepúlveda Pertence e Célio Borja. 
decisão proferida pela Casa Legislativa; b) a decisão não deve reverência aos rigores de objetividade e motivação que se impõem aos pronunciamentos judiciais (CF, art. 93, IX).

Nada obstante, a despeito de posições minoritárias dissonantes, afirmou-se, com a chancela da jurisprudência reiterada do Supremo Tribunal Federal, ${ }^{5}$ a tese de cabimento de controle judicial dos atos praticados no processo por crime de responsabilidade perante órgão legislativo. Por evidente, como assinalado, não caberá a revisão de mérito, mas, sim, se a competência constitucional foi exercida nos seus legítimos limites e se não ocorreu violação a direitos subjetivos.

No que diz respeito às partes, é de se assinalar, de plano, não ser cabível uma analogia rigorosa com o processo judicial típico, notadamente no que diz respeito ao pólo ativo. No pólo passivo, estão sujeitos ao processo por crime de responsabilidade o Presidente da República, os Ministros de Estado, os Ministros do STF, o Procurador-Geral da República, os Governadores e Secretários de Estado. Veja-se que no caso do Presidente e seus Ministros, assim como do Governador e seus Secretários (Lei 1.079/50, arts. 14 e 75), o denunciante apresenta mera notitia criminis, não se tornando parte ativa nem integrando o processo.

Os fundamentos do pedido de impeachment são os fatos tipificados em lei como crime de responsabilidade, em desenvolvimento do delineamento constitucional inscrito no art. 85, in verbis:

“Art. 85. São crimes de responsabilidade os atos do Presidente da República que atentem contra a Constituição Federal e, especialmente, contra:

I - a existência da União;

II - o livre exercício do Poder Legislativo, do Poder Judiciário, do Ministério Público e dos Poderes constitucionais das unidades da Federação;

III - o exercício dos direitos políticos, individuais e sociais;

IV - a segurança interna do País;

$\mathrm{V}$ - a probidade na administração;

VII - o cumprimento das leis e das decisões judiciais.

Parágrafo único. Esses crimes serão definidos em lei especial, que estabelecerá as normas de processo e julgamento."

Assinale-se, por ora, para desenvolvimento posterior, a circunstância relevante de que a Constituição em vigor, tal como a de 1967-69, mas em contraste com a de 1946, não incluiu no elenco de crimes de responsabilidade "a guarda e o legal emprego dos dinheiros públicos", que aquela Carta contemplava no inciso VII do art. 89, e a Lei $1.059 / 50$ desenvolveu no art. $11 .^{7}$

5 V., e.g., acórdãos nos Mandados de Segurança 20.941, 21.564 e 21.689.

6 Estes os agentes políticos constantes da Lei 1.079/50. O Decreto-lei $n^{2} 201$, de 27/02/67, cuida da responsabilização de Prefeitos e Vereadores.

7 O art. 89 da CF de 1946 tinha a seguinte redação: "Art. 89. São crimes de responsabilidade os atos do Presidente da República que atentarem contra a Constituição Federal e, especialmente, contra:

I - a existência da União;

II - o livre exercício do Poder Legislativo, do Poder Judiciário e dos poderes constitucionais dos Estados; 
A prévia autorização do órgão legislativo para a instauração de processo contra o Chefe do Executivo é exigida tanto nos casos de crime comum como nos de crime de responsabilidade. Concedida autorização, o julgamento realizar-se-á perante o Poder Judiciário, na primeira hipótese, ou perante o próprio Poder Legislativo, na segunda. Consoante o modelo federal inscrito no parágrafo único do art. 52 , transplantado para os Estados-membros, ${ }^{8}$ são duas as penas estabelecidas para os crimes de responsabilidade: a) perda do cargo; b) inabilitação, por oito anos, para o exercício de função pública. Confira-se a diç̧ão constitucional, in verbis:

“Art. 52

Parágrafo único. Nos casos previstos nos incisos I e II, funcionará como Presidente o do Supremo Tribunal Federal, limitando-se a condenação, que somente será proferida por dois terços dos votos do Senado Federal, à perda do cargo, com inabilitação, por oito anos, para o exercício de função pública, sem prejuízo das demais sanções judiciais cabíveis".

O tema foi amplamente discutido no Supremo Tribunal Federal, quando do julgamento do MS 21.689-DF, restando consignado na ementa do acórdão:

"A existência, no "impeachment" brasileiro, segundo a Constituição e o direito comum (CF, 1988, art. 52, parágrafo único; Lei no 1.079, de 1950, artigos 2o, 33 e 34), de duas penas: a) perda do cargo; b) inabilitação, por oito anos, para o exercício de função pública".

Repassados, assim, os conceitos fundamentais sobre o tema, tal como desenvolvidos pela doutrina e abrigados pela mais alta Corte, passa-se, a seguir, à sua aplicação à hipótese concreta em exame.

\section{Não é possivel a instauração de processo por crime de responsabilidade quando o acusado não mais ocupe o cargo do qual era passivel de destituição}

Consoante informa, documentadamente, o consulente, o impetrante teve sua exoneração concedida em 30 de junho de 1997, por ato do Governador do Estado publicado no Diário Oficial do mesmo dia, e que circulou no dia $1^{9}$ de julho seguinte. Somente no dia 2 de julho o Presidente da Assembléia Legislativa submeteu à votação o Projeto de Decreto Legislativo $n^{2}$ 057/97, cujo objeto era, precisamente, “instaurar

III - o exercício dos direitos políticos, individuais e sociais;

IV - a segurança interna do país;

$V$ - a probidade na administração;

VI - a lei orçamentária;

VII - a guarda e o legal emprego dos dinheiros públicos;

VIII - o cumprimento das decisões judiciárias.

Parágrafo único. Esses crimes serão definidos em lei especial, que estabelecerá as normas de processo e julgamento".

8 A Constituição do Estado de Santa Catarina dispõe em seu art. 40, parágrafo único: "Nos casos previstos nos incisos XX e XXI, funcionará como presidente o do Tribunal de Justiça, limitando-se a condenação, que somente será proferida por dois terços dos votos de seus membros, à perda do cargo, com inabilitação por oito anos para o exercício de função pública, sem prejuízo das demais sançōes judiciais cabíveis". 
processo por crime de responsabilidade contra o Senhor Paulo Sérgio Gallotti Prisco Paraíso, Secretário de Estado da Fazenda".

Naquela altura, todavia, já não era mais possível a instauração do processo. A tese é singela e incontroversa.

A Lei 1.079 , de 10 de abril de 1950 , que, como se deixou assentado, foi recepcionada em sua maior porção pela Constituição de 1988 , fornece o roteiro para equacionamento e solução da questão posta. Confiram-se, a propósito, os arts. 15 , 76, parágrafo único, e 79 parágrafo único do indigitado diploma legal:

“DO PRESIDENTE DA REPÚBLICA E MINISTROS DE ESTADO

Art. 15. A denúncia só poderá ser recebida enquanto o denunciado não tiver, por qualquer motivo, deixado definitivamente o cargo."

DOS GOVERNADORES E SECRETÁRIOS DOS ESTADOS

"Art. 76

Parágrafo único. Não será recebida a denúncia depois que o governador, por qualquer motivo, houver deixado definitivamente o cargo."

"Art. 79

Parágrafo único. Os secretários de Estado, nos crimes conexos com os dos governadores, serão sujeitos ao mesmo processo e julgamento."

As normas em questão estabelecem, de modo uniforme para os agentes políticos federais - Presidente da República e Ministros de Estado - e estaduais - Governadores e Secretários de Estado — , uma condição de procedibilidade para a instauração do processo de impeachment. Com efeito, não admite a lei seja a denúncia por crime dessa natureza recebida caso o agente político tenha, por qualquer motivo, deixado definitivamente o cargo.

Esta é a posição da doutrina especializada, como se vê, e.g.:

“ $O$ art. 15 da Lei $n^{\prime}$ 1.079/50 estabelece uma condição objetiva de procedibilidade para a aceitação da denúncia, eis que vincula o recebimento da peça acusatória ao fato de o Presidente estar no exercício do cargo. bilidade."

(...) Portanto, trata-se de uma condição de procedibilidade e também de puni-

A matéria foi longamente analisada pelo Supremo Tribunal Federal quando do julgamento do Mandado de Segurança $\mathrm{n}^{\mathrm{Q}}$ 21.564-DF, impetrado pelo ex-Presidente Collor de Mello. A hipótese então em discussão estremava-se da que é objeto do presente parecer pelo fato de que o ex-Presidente renunciou ao cargo durante a sessão de julgamento pelo Senado Federal, muito tempo depois de ter sido tecnicamente recebida a denúncia e instaurado o processo por crime de responsabilidade. Na hipótese aqui versada, o impetrante deixou o cargo de Secretário de Estado em data anterior à instauração do processo.

A posição do Supremo Tribunal Federal é inequívoca, e materializou-se na própria ementa do acórdão, cujo item III tem a seguinte dicção:

“III - Alteração do direito positivo brasileiro: a Lei $n^{\circ} 27$, de 1892, art. 3", estabelecia: a) o processo de impeachment somente poderia ser intentado durante $o$ período presidencial; b) intentado, cessaria quando o Presidente, por qualquer 
motivo, deixasse definitivamente o exercício do cargo. A Lei no 1.079, de 1950, estabelece, apenas, no seu art. 15 , que a denúncia só poderá ser recebida enquanto o denunciado não tiver, por qualquer motivo, deixado definitivamente o cargo."

A ênfase do acórdão, nessa parte, recaiu na modificação legislativa que repercutiu sobre os efeitos da saída do agente político do cargo. Presentemente, inexiste norma prevendo a extinção do processo quando, após sua instauração, venha a operar-se a vacância do cargo. Manteve-se, todavia, regra expressa vedando a instauração do processo quando o acusado, por qualquer motivo, houver deixado definitivamente o cargo. É o que se colhe, didaticamente, do voto do Ministro Sepúlveda Pertence a seguir transcrito, verbis:

"Donde, coerentemente, no art. 15 da lei $n^{2} 1.079 / 50$, a redução a uma só das duas conseqüências que a lei velha, também coerentemente, imputava ao mesmo fato - ter o denunciado, por qualquer motivo, deixado definitivamente o cargo: antes, a vedação de intentar-se o processo ou a extinção do processo já instaurado; hoje, apenas a impossibilidade de receber-se a denúncia, após a vacância do cargo." (grifos acrescentados).

Cabe fazer uma observação final relevante acerca desse julgado do Supremo Tribunal Federal. O acórdão, por maioria apertada obtida com a convocação de Ministros do Superior Tribunal de Justiça, concluiu que a renúncia, quando já iniciado o julgamento - isto é, com o processo em curso e já em sua fase final não paralisa o processo. Os quatro votos vencidos - dos Ministros Ilmar Galvão, Celso de Mello, Moreira Alves e Octávio Gallotti - entenderam que a saída do agente político do cargo tornava sem objeto o processo de impeachment já instaurado. É natural a inferência de que, mantida a composição, a posição unânime do Supremo Tribunal Federal é no sentido do descabimento de processo de impeachment se o acusado já não estiver no cargo no momento de oferecimento da denúncia, como prevê de forma expressa a Lei $n^{2} 1.079 / 50$.

A aplicabilidade dos princípios, regras e conceitos acima enunciados aos Secretários de Estado é fora de dúvida. Em primeiro lugar, por previsão expressa da Lei 1.079/50, que dedica sua "Parte Quarta" aos Governadores e Secretários de Estado, e onde se colhem os dispositivos transcritos ao início deste capítulo (parágrafos únicos dos arts. 76 e 79). Em segundo lugar, porque não há na legislação estadual de qualquer nível norma provendo em sentido diverso. E, ainda quando houvesse, não resistiria ao contraste constitucional.

III. Em face da legislação aplicável, o ato de instauração do processo de impeachment é a aprovação pela Assembléia Legislativa, por quorum constitucional de dois terços dos seus membros, do Projeto de Decreto Legislativo previsto regimentalmente, e não a mera aprovação do parecer da Comissão Parlamentar Especial

Dispõe a Lei $1.079 / 50$, em seu art. 79:

“Art. 79. No processo e julgamento dos governadores serão subsidiários desta Lei, naquilo em que lhe forem aplicáveis, assim o regimento interno da Assembléia Legislativa e do Tribunal de Justiça, como o Código de Processo Penal". 
Em harmonia com o regramento federal, a Constituição do Estado de Santa Catarina estabelece, em seu art. 73, que o Governador será submetido a processo e julgamento perante a Assembléia Legislativa, por crimes de responsabilidade, depois de declarada, pelo voto de $2 / 3$ de seus membros, a procedência da acusação. $O$ art. 75 submete os Secretários de Estado ao mesmo processo e julgamento do Governador, nos crimes conexos.

Por sua vez, o Regimento Interno da Assembléia Legislativa, promulgado como Resolução DP $n^{\circledR} 47$, de 4 de dezembro de 1989, dedica seus arts. 243 a 245 ao "processo nos crimes de responsabilidade do Governador e dos Secretários de Estado". O $§ 1^{\circ}$ do art. 243 prevê a apreciação preliminar da acusação (denominada no Regimento de representação) por uma "Comissão Especial, constituída de um quinto dos membros da Assembléia com observância da proporcionalidade partidária, para emitir parecer sobre a representação e as informações, no prazo máximo de quinze dias a contar de sua instalação". O $\S 2^{\circ}$ do mesmo artigo prevê hipóteses de prorrogação do prazo para trinta ou sessenta dias. Em dispositivo especialmente relevante para os fins aqui visados, determina o § $3^{\circ}$ do art. 243 , in verbis:

"§ 3․ O parecer da Comissão Especial concluirá, em projeto de decreto legislativo, pelo recebimento ou não da representação".

O Regimento Interno, portanto, em regra de meridiana clareza, sem margem a interpretações complexas ou ambíguas, estabelece que o parecer concluirá apresentando um projeto de decreto legislativo. Em seguida, o $\$ 4^{\circ}$ do art. 243 , também em linguagem cristalina, preceitua:

“ $\$ 4^{\circ}$ Caso seja aprovado o projeto, por dois terços dos membros da Assembléia concluindo pelo recebimento da representação, para os efeitos de direito, o Presidente promulgará o decreto legislativo, do qual fará chegar uma via ao substituto constitucional do Governador para que assuma o poder, no dia em que entre em vigor a decisão da Assembléia."

Cabe observar que o Supremo Tribunal Federal, na apreciação da medida cautelar impetrada na ADIN no 1.628 -SC, suspendeu a eficácia do trecho não grifado, o que é, todavia, inteiramente irrelevante para a discussão aqui desenvolvida. Pois bem: como resulta superlativamente evidente do preceptivo transcrito, é a aprovação do projeto de decreto legislativo que importa no recebimento da representação (rectius: da denúncia), e não qualquer outro ato. Aliás, é por esta razão que a ementa do Projeto de Decreto Legislativo $\mathrm{n}^{\mathrm{Q}}$ 57/97, resultante de projeto apresentado pela Comissão Especial, dispõe: "Autoriza a instauração de processo por crime de responsabilidade". Confira-se a íntegra do referido ato legislativo, aprovado como Decreto Legislativo $\mathrm{n}^{\mathrm{Q}} 17.810$, de 2.07.97:

"Autoriza a instauração de processo por crime de responsabilidade.

O Presidente da Assembléia Legislativa do Estado de Santa Catarina, faz saber a todos os habitantes deste Estado que ela aprovou e ele promulga o seguinte DECRETO LEGISLATIVO:

Art. 1ำ Fica autorizada, a Assembléia Legislativa do Estado de Santa Catarina, nos termos do Artigo 40, incisos XVI e XX, da Constituição Estadual, a instaurar processo por crime de responsabilidade contra o Senhor PAULO SÉRGIO GALLOTTI PRISCO PARAÍSO, Secretário de Estado da Fazenda. 
Art. $2^{\circ}$ Este Decreto Legislativo entra em vigor na data de sua publicação.

Art. $3^{2}$ Revogam-se as disposições em contrário."

À vista do que acima se expôs e transcreveu, não é relevante, nas circunstâncias, o fato de que o Plenário da Assembléia Legislativa tenha aprovado, com qualquer quorum, o parecer da Comissão Especial. É que somente com a aprovação e a promulgação do decreto legislativo deve-se considerar recebida a denúncia, "para os efeitos de direito", como explicita o próprio dispositivo. Assim, a aprovação do parecer da Comissão Especial no Plenário da Casa Legislativa não supre, por evidente, a necessidade de discussão e votação do projeto de decreto legislativo.

E assim é, não apenas por força da literalidade e do espírito da regra, como por outras razões que se cumulam. Em primeiro lugar porque o procedimento legislativo não é facultativo, nem fungivel. Bem ao revés, tem ele caráter vinculado e sujeito à reserva legal absoluta. Logo, onde a norma de regência exige decreto legislativo, não se pode suprir com parecer de comissão.

Segundo, porque da aprovação do parecer da Comissão Especial no Plenário não se extrai como consequiência, a fortiori, a aprovação do projeto de decreto legislativo que oferece. De fato, nada garante que as forças políticas não se aglutinarão de uma outra forma, provocando uma alteração na votação, ou que aquilo que obteve aprovação em bloco (parecer) não tenha o mesmo êxito em separado (projetos de decretos legislativos).

Em conclusão: a instauração do processo por crime de responsabilidade, por força da legislação aplicável - Lei 1.079/50, Constituição do Estado de Santa Catarina e Regimento Interno da Assembléia Legislativa - somente se dá mediante aprovação, por dois terços, do Projeto de Decreto Legislativo apresentado pela Comissão Especial e submetido a Plenário. Ora bem: este decreto legislativo, é incontroverso, somente foi votado em 2 de julho de 1997, quando o impetrante da segurança não mais ocupava o cargo de Secretário de Estado desde o dia 30 de junho anterior.

\section{O requisito para instauração do processo por crime de responsabilidade é} que o agente político não tenha deixado o cargo. É indiferente, para os fins da legislação, se a hipótese foi de renúncia ou de exoneração

Os institutos jurídicos da renúncia e da exoneração, naturalmente, abrigam conteúdos diversos. A renúncia configura ato unilateral do agente público, mediante o qual expressa a vontade de deixar o cargo que ocupa. ${ }^{10} \mathrm{~A}$ exoneração é a cessação da relação jurídico-funcional do servidor, sem caráter de sanção. Pode ela se dar a pedido ou ex officio, neste último caso quando se tratar de cargo em comissão ou, no caso de cargo efetivo, quando não satisfeitas as exigências do estágio probatório ou quando, tendo tomado posse, o servidor não entrar em exercício no prazo estabelecido. Há consenso em que a exoneração não tem caráter de penalidade."

10 V., por todos, Benjamin Villegas Basavilbaso, Tratado, 1955, vol. I, p. 355.

11 V., por todos, Maria Sylvia Zanella di Pietro, Direito Administrativo Brasileiro, 1997, p. 384. 
É bem de ver, no entanto, que a distinção entre as duas figuras, que pode ter grande relevância em outras circunstâncias, é totalmente inócua na hipótese sob exame. Igualam-se uma e outra no efeito que aqui interessa que é a vacância do cargo. De fato, os artigos 15 e 76 da Lei no $1.079 / 50$ estabelecem que a denúncia por crime de responsabilidade só poderá ser recebida enquanto o agente político denunciado, por qualquer motivo, "não houver deixado definitivamente o cargo". A expressão utilizada pelo legislador é propositadamente ampla, servindo para designar toda e qualquer hipótese de saída do cargo em caráter definitivo. Em nenhum momento a palavra renúncia é utilizada.

Portanto, configurada a vacância do cargo, seja por renúncia - para os agentes políticos que detêm mandato popular - seja por exoneração ou por qualquer outra forma para os demais, incide a vedação legal genérica para instauração de processo de impeachment. Não pode o intérprete fazer uma distinção arbitrária, que não tem fundamento legítimo no relato da norma.

Não se afigura pertinente, de outra parte, a invocação da legislação genérica de regência do regime jurídico funcional dos servidores públicos. Em primeiro lugar, à toda evidência, pela existência de lei específica. Em segundo lugar, porque tanto a lei federal do regime jurídico único - Lei 8.112, de 11.12.90, art. $172^{12}-$, como o Estatuto dos Funcionários Públicos de Santa Catarina, no art. $163,{ }^{13}$ restringem a faculdade de requerer exoneração "ao servidor que estiver respondendo a processo disciplinar". Nem a mais arrebatada das interpretações livres haveria de considerar o impeachment um processo disciplinar. De fato, o processo por crime de responsabilidade tem por finalidade, como visto no capitulo introdutório, a destituição do agente político do cargo e sua inabilitação para o exercício de função pública por um determinado período. Tais penalidades, intuitivamente, não se confundem com as que resultam do processo administrativo de responsabilização interna do servidor.

Reitere-se a evidência: não há como confundir o processo de impeachment, que versa sobre a prática de crimes de responsabilidade e tem o objeto acima referido, com o processo administrativo disciplinar, que tem por fim a aplicação de sanções administrativas - como a advertência, a suspensão e a demissão - ao servidor que tenha violado seus deveres funcionais. Ademais, enquanto o primeiro é levado a efeito pelo Poder Legislativo, o segundo é conduzido no âmbito interno do Poder a que pertence o servidor acusado.

Pois bem: nenhum processo administrativo disciplinar fora instaurado contra o impetrante. A denúncia oferecida perante o Presidente da Assembléia Legislativa lhe imputava a suposta prática de crime de responsabilidade, previsto na Lei $\mathrm{n}^{\mathrm{Q}}$ 1.079/50. Assim, não tem aplicabilidade ao caso o art. 163 do Estatuto dos Servidores Públicos do Estado. Ainda que assim não fosse, isto é, ainda que o consulente estivesse respondendo a processo administrativo disciplinar, o aludido dispositivo

12 O dispositivo tem o seguinte teor: “Art. 172. O servidor que responder a processo disciplinar só poderá ser exonerado a pedido, ou aposentado voluntariamente, após a conclusāo do processo e o cumprimento da penalidade, acaso aplicada".

13 O dispositivo tem o seguinte teor: "Art. 163. O funcionário que estiver respondendo a processo disciplinar não poderá, antes de seu término, ser exonerado a pedido, nem se afastar do serviço, a não ser em virtude de licença por doença, suspensão preventiva, prisāo administrativa ou prisão em flagrante". 
não teria o condão de impedir os efeitos de sua exoneração para os fins do processo de impeachment.

De fato, o que pretendeu o Estatuto foi tornar a exoneração inoponível à Administração Pública, de modo a evitar que o servidor se subtraísse à aplicação da sanção administrativa por meio deste procedimento. O dispositivo estatutário, portanto, tem sua aplicabilidade limitada ao âmbito do processo disciplinar, com vistas a assegurar a aplicação da pena administrativa, não se estendendo a processos de outra natureza.

V. Os crimes de responsabilidade a serem definidos em lei especial, como prevê o parágrafo único do art. 85 da Constituição Federal, só podem ser os que correspondam às figuras típicas constantes do corpo do dispositivo. Trata-se de matéria de reserva constitucional, insuscetível de extensão discricionária por parte do legislador

Todas as Constituições republicanas brasileiras, a partir de 1891, capitularam, em caráter esquemático, as figuras típicas referentes aos crimes de responsabilidade, prevendo sua definição em lei ordinária especial. A Constituição em vigor explicita, nos sete incisos do art. 85, já reproduzidos no capítulo I deste parecer, os bens jurídicos a serem tutelados mediante a imputação de crimes de responsabilidade. $O$ parágrafo único do artigo prevê expressamente: "Esses crimes serão definidos em lei especial, que estabelecerá as normas de processo e julgamento".

A Constituição, como se constata singelamente, atribuiu ao legislador infraconstitucional a disciplina substantiva e processual da matéria, salvo naquilo que reservou para si própria. Assim, por exemplo, não poderá a lei ordinária, ao cuidar do processo, dispor acerca das competências da Câmara e do Senado de modo diverso do já feito pelo constituinte. Da mesma forma, ao tratar das definições dos crimes, não poderá incluir categoria diversa das que se encontram no elenco do art. 85. É intuitivo que seja assim, como captou a pena sempre arguta de José Afonso da Silva, in verbis:

“Todos esses crimes serão definidos em lei especial, que estabelecerá as normas de processo e julgamento (art. 85, parágrafo único, já existindo a propósito a Lei $n^{\circ}$ 1.079/50), respeitados naturalmente as figuras típicas e os objetos materiais circunscritos nos incisos do art. 85." 14 (grifos acrescentados).

É possível afirmar, por via de consequiência, que os crimes de responsabilidade se submetem, no direito brasileiro, a um regime de tipologia constitucional estrita, cabendo ao legislador ordinário tão-somente explicitar e minudenciar práticas que se subsumam aos tipos constitucionais.

A Lei $\mathrm{n}^{\mathrm{Q}}$ 1.079/50, que, como já assinalado por mais de uma vez, é reconhecida como a lei de que trata o parágrafo único do art. 85 da Constituição, reserva os oito capítulos de seu Título I à definição dos crimes de responsabilidade, seguindo o 
roteiro da previsão constitucional. Assim, as diversas figuras típicas e objetos jurídicos elencados nos incisos do art. 85 são, um a um, regulamentados nos arts. $5^{\ominus}$ a 12 da Lei.

Nada obstante, em um dispositivo específico, a Lei $1.079 / 50$ perde a sintonia com a Lei Maior: o art. 11, inserto no Capítulo VII, tipifica como crimes de responsabilidade condutas que não têm correspondência na matriz constitucional. Com efeito, tal preceptivo versa sobre "crimes de responsabilidade contra a guarda e o legal emprego dos dinheiros públicos", figura típica que não consta do elenco do art. 85 da Constituição.

A existência do art. 11 da Lei nº 1.079/50, no entanto, é facilmente explicável. É que a Constituição de 1946, sob cuja égide a Lei $n^{2} 1.079$ foi editada, estabelecia, no inciso VII de seu art. 89 , precisamente, a figura típica do crime de responsabilidade contra "a guarda e o legal emprego dos dinheiros públicos", como haviam feito todas as Constituições até então. ${ }^{15}$ Desse modo, era natural que a lei infraconstitucional destinasse um de seus capítulos à definição de condutas que configurariam tal tipo penal. Todavia, esta figura típica foi suprimida dos textos da Constituição de 1967 e da Emenda Constitucional nº 01/69, não havendo sido reproduzida na Constituição de 1988.

A supressão de um dos tipos do elenco constitucional de crimes de responsabilidade produz, em última análise, os efeitos de uma abolitio criminis. Com efeito, todos os fatos anteriormente criminalizados tornam-se, ipso facto, atípicos, não mais ensejando qualquer consequiência na esfera da responsabilidade política. Coerente com a premissa de que todas as figuras típicas dos crimes de responsabilidade encontram-se sujeitas a regime de reserva constitucional estrita, é inarredável a conclusão de que $o$ art. 11 da Lei $n^{0} 1.079 / 50$ não foi recepcionado pela ordem constitucional vigente.

Segundo relato do ilustre consulente, instruído com os documentos do processo, a única imputação que pesa contra seu cliente é a de "ordenar despesas não autorizadas por lei ou sem observância das prescrições legais relativas às mesmas", conduta prevista, precisamente, no art. $11, n^{\circ} 1$, da Lei $n^{2} 1.079 / 50$, que trata dos crimes de responsabilidade contra a guarda e o legal emprego dos dinheiros públicos.

Não resta dúvida, portanto, que a acusação atribui ao impetrante a prática de fato manifestamente atípico (ao menos do ponto de vista dos crimes de responsabilidade), uma vez que a norma legal incriminadora que lhe dava suporte foi revogada ainda em 1967, pela Constituição Federal editada naquele ano. ${ }^{16}$ Embora irrelevante para a hipótese aqui examinada, ainda que a revogação se tivesse operado após a prática do fato, o efeito seria idêntico, por força da abolitio criminis.

15 CF 1989, art. 54, 7\%; CF 1934, art. 57, g; CF 1937, art. 85, d.

16 A jurisprudência do Supremo Tribunal Federal no sentido de que a nova Constituição revoga as leis anteriores, quando com ela incompatíveis, é antiga, havendo sido recentemente ratificada, após ampla discussão, no julgamento da ADIn $n^{2} 2$, da qual foi relator o então Ministro Paulo Brossard. Sobre o tema. v. nosso Interpretação e aplicaçāo da Constituição, Ed. Saraiva, 1996, p. 64 e ss. 
É fora de dúvida, por outro lado, que o Poder Judiciário está autorizado a exercer o controle da legalidade sobre o processo de impeachment, salvaguardando eventual direito subjetivo violado, conforme o já mencionado entendimento consolidado na jurisprudência do Supremo Tribunal Federal. A hipótese em questão enseja, de modo claro e inequívoco, o judicial review. Confira-se, a propósito, significativo trecho do voto do Ministro Sepúlveda Pertence no julgamento do Mandado de Segurança $\mathrm{n}^{2}$ 21.546-DF, in verbis:

“Desse modo, Senhor Presidente, não excluo, por exemplo, que caiba ao Poder judiciário a verificação da existência, em tese, da imputação de um crime de responsabilidade, dada a exigência constitucional, que é peculiar ao nosso sistema, de sua tipificação em lei, ainda que não exclua a ampla discricionariedade e a exclusividade do juízo do Senado na concretização dos conceitos indeterminados da definição legal típica dos crimes de responsabilidade." (grifos acrescentados).

Como se vê, admite o Ministro Sepúlveda Pertence, como não poderia deixar de ser, que o Poder Judiciário exerça controle sobre a tipicidade dos fatos objetos de imputação em processo por crime de responsabilidade. A ressalva quanto à margem de discricionariedade das Casas legislativas é correta, mas não interfere minimamente com o caso vertente. É que a verificação da atipicidade da imputação não depende aqui da análise de fatos ou provas, sendo pura questão de direito. Também não se está diante da concretização de conceitos legais indeterminados, que estariam a cargo exclusivo do Poder Legislativo.

A análise da atipicidade, na hipótese, depende de raciocínio puramente jurídico. Cuida-se, apenas, de reconhecer que o fato imputado ao impetrante não enseja a instauração de processo por crime de responsabilidade, pois o dispositivo legal que continha tal previsão foi revogado. Estabelecida a premissa, a conclusão é inafastável: deve o Poder Judiciário determinar o trancamento do processo de impeachment instaurado contra o impetrante, eis que fundado em imputação de fato manifestamente atípico.

\section{Conclusão}

Em face do que foi exposto, e ratificando as proposições enunciadas ao início do presente estudo, é possível compendiar as idéias aqui desenvolvidas nas seguintes conclusões:

1. Não é legítima a instauração de processo por crime de responsabilidade contra acusado que já tenha deixado o cargo público que ocupava;

2. À vista da legislação aplicável - Lei 1.079/50, Constituição do Estado de Santa Catarina e Regimento Interno da Assembléia Legislativa do Estado de Santa Catarina -, a instauração do processo por crime de responsabilidade somente se dá pela aprovação do projeto de decreto legislativo apresentado pela Comissão Especial, cujo objeto específico é, precisamente, a autorização para deflagração do impeachment; 
3. O que impede a instauração do processo por crime de responsabilidade é o fato de o agente político haver deixado o cargo, sendo irrelevante, para este fim, se a hipótese foi de renúncia ou exoneração.

4. A lei ordinária só pode definir como crimes de responsabilidade as figuras típicas constantes do elenco constitucional do art. 85. Suprimida, por Constituição superveniente, hipótese existente nas Cartas anteriores, perdem a vigência os dispositivos da Lei $1.079 / 50$ que desenvolviam a figura típica abolida.

É como me parece. 